\title{
Xylella fastidiosa subsp. pauca and fastidiosa Colonize Arabidopsis Systemically and Induce Anthocyanin Accumulation in Infected Leaves
}

\author{
W. E. L. Pereira, C. B. Ferreira, R. Caserta, M. Melotto, and A. A. de Souza ${ }^{\dagger}$
}

First, second, third, and fifth authors: Centro de Citricultura Sylvio Moreira-Instituto Agronômico, Cordeirópolis, SP, Brazil; first and second authors: Universidade Estadual de Campinas (Unicamp), Campinas, SP, Brazil; and first and fourth authors: Department of Plant Sciences, University of California, Davis.

Accepted for publication 22 July 2018.

\begin{abstract}
The bacterium Xylella fastidiosa is a multihost pathogen that affects perennial crops such as grapevine, sweet orange, and olive tree worldwide. It is inherently difficult to study these pathosystems owing to the long-term growth habit of the host plant. Thus, the availability of model plants becomes essential to accelerate discoveries with economic impact. In this study, we uncovered evidence that the model plant Arabidopsis thaliana can be colonized by two different $X$. fastidiosa subspecies, pauca and fastidiosa. We observed that these bacteria are able to move away from the inoculation point as high bacterial populations were found in

bacterium to move against the net xylem flow during the time course of colonization forming biofilm. These findings provide evidence for the capacity of $X$. fastidiosa to colonize Arabidopsis. Furthermore, leaves inoculated with $X$. fastidiosa showed a significant accumulation of anthocyanin. We propose that the X. fastidiosa subsp. pauca or fastidiosa colonization pattern and anthocyanin accumulation in the Arabidopsis ecotype Col- 0 can be used as marker phenotypes to facilitate further studies aimed at improving genetic components involved in $X$. fastidiosa-host interaction.
\end{abstract} distant tissues. In addition, confocal laser scanning microscopy analysis of bacterial movement inside the petiole revealed the ability of the
Additional keywords: Xylella-Arabidopsis interaction.
Xylella fastidiosa is a xylem-limited plant pathogen that causes diseases in more than 100 plant species including many crops such as citrus, grape, almond, coffee, and plum among others (Rapicavoli et al. 2018). Until very recently this phytopathogen has caused crop damage only in the Americas; however, in 2013 it was found to cause the olive quick decline syndrome (OQDS), a disease responsible for the death of thousands of olive trees in southern Italy (Saponari et al. 2013). Since then, the bacterium has been found in other countries and is a reason for great concerns regarding food security in the European Union. $X$. fastidiosa is now considered a quarantine pathogen included in the European and Mediterranean Plant Protection Organization (EPPO) A 1 list (Mang et al. 2016).

Currently, X. fastidiosa is divided into five subspecies: fastidiosa, pauca, multiplex, sandyi, and morus (Almeida and Nunney 2015).

\section{${ }^{\dagger}$ Corresponding author: A. A. de Souza; E-mail: desouza@ccsm.br}

Funding: Support was provided by UC Davis-Fundação de Amparo à Pesquisa do Estado de São Paulo SPRINT joint program (2015/50462-6; 2013/10957-0) for the research award to M. Melotto and A. A. De Souza, the Brazilian National Council for Scientific and Technology Development of the Ministry of Science, Technology, and Innovation (CNPq/MCTI) for a Special Visiting Researcher fellowship to M. Melotto, a Visiting Ph.D. Student scholarship to W. E. L. Pereira, and a research award to A. A. De Souza under Conselho Nacional de Desenvolvimento Científico e Tecnológico the Science Without Borders program (405004/2013-3). R. Caserta and W. E. L. Pereira were supported by a fellowship from CNPq (PDJ 150820/ 2015-1 and 202762/2015-7) and FAPESP (2016/01273-9), respectively. A. A. De Souza is recipient of a research fellowship from CNPq. W. E. L. Pereira and C. B. Ferreira are Ph.D. students in the Genetics and Molecular Biology Program at the Institute of Biology, State University of Campinas (UNICAMP).

First and second authors contributed equally to this work.

Author Contributions: A.A.D.S. conceived this project. M.M. and A.A.D.S. designed all research. W.E.L.P., C.B.F., and R.C. performed the experiments. W.E. L.P., C.B.F., M.M., and A.A.D.S. analyzed the data. M.M. and A.A.D.S. provided materials. W.E.L.P., M.M., and A.A.D.S. wrote the article.

(c) 2019 The American Phytopathological Society
Subspecies fastidiosa and pauca are the most widely studied as they cause economic damage in important crops such as grapevines in the North and Central America ( $X$. fastidiosa subsp. fastidiosa) as well as citrus and olive (X. fastidiosa subsp. pauca) in South America and Italy (Bové and Ayres 2007; Luvisi et al. 2017a; Tumber et al. 2014). The existence of different level of host susceptibility is well recognized in these pathosystems. For instance, there are susceptible and resistant varieties of grape in response to $X$. fastidiosa (Baccari and Lindow 2010; Fry and Milholland 1990). Plant resistance and susceptible are also observed in citrus (Coletta-Filho et al. 2007; Niza et al. 2015) and olive (Giampetruzzi et al. 2016; Luvisi et al. 2017b), providing the opportunity to identify defense response-associated genes in the plant host that could impair $X$. fastidiosa colonization (Chakraborty et al. 2016; De Souza et al. 2007; Giampetruzzi et al. 2016; Lin et al. 2007; Rodrigues et al. 2013; Yang et al. 2011). Although these studies have contributed significantly to the knowledge regarding Xylella-plant interactions, the functionality of the genes identified remains elusive. A major impediment to advance current knowledge on the function of defense-associated gene in this pathosystem is the slow growth of the perennial hosts and the long incubation period for symptom development (Almeida et al. 2001; ColettaFilho et al. 2007; Saponari et al. 2017). In addition, genetic transformation using perennial crops such as grapevines, citrus, and olive are very laborious due to the long juvenile period necessary to analyze the gene function during pathogen colonization (Mencuccini et al. 1999; Peña et al. 2001; Saporta et al. 2016).

The model plant Arabidopsis is widely used to study many aspects of plant-pathogen interactions (Windram et al. 2012; Witzel et al. 2015) owing to the large and readily available collection of mutants (Alonso et al. 2003), fast growth habit and established genetic transformation protocols (Clough and Bent 1998), and comprehensive literature on plant responses to pathogens (Schlaich 2011). Thus, we sought to establish a robust procedure to investigate the function of $X$. fastidiosa defense-associated gene using Arabidopsis as a potential host plant. Here, we show that the Arabidopsis ecotype 
Col-0 can be a model host for two different subspecies of $X$. fastidiosa, subsp. pauca and fastidiosa. These bacteria colonize the xylem vessel of the floral stem, roots, and leaves during the time course of colonization. Moreover, we found a significant accumulation of anthocyanin in leaves inoculated with $X$. fastidiosa providing an opportunity to use this phenotype as a quantitative marker for plant colonization. This newly discovered pathosystem will facilitate further studies aimed at improving genetic resistance against $X$. fastidiosa.

\section{MATERIALS AND METHODS}

A. thaliana ecotypes and $X$. fastidiosa inoculation. The bacterial strains $X$. fastidiosa subsp. pauca 9a5c (Simpson et al. 2000) and X. fastidiosa subsp. fastidiosa Temecula-1 (Van Sluys et al. 2012) were cultured on Periwinkle wilt (PWG) media (Davis et al. 1981) for 5 days at $28^{\circ} \mathrm{C}$ in a BOD incubator (TE-391, Tecnal, Piracicaba, SP). Bacterial cells were harvested from the plates with $1 \mathrm{ml}$ of phosphate buffered saline (PBS) buffer and centrifuged for $1 \mathrm{~min}$ at $16,000 \times \mathrm{g}$. Cell pellets were suspended in sterile, deionized water to an optical density (OD) of $0.2,0.7$, or 2.0 to inoculate different Arabidopsis ecotypes (Col-0, Tsu-1, and Van1). Additionally, the bacterial concentration in the inoculum was determined using the serial dilution plating method. Briefly, each 10-fold dilution was plated on Petri dishes containing PWG and incubated at $28^{\circ} \mathrm{C}$. After 30 days, the number of colony forming units (CFU) on each plate was counted to estimate the inoculum concentration $(\mathrm{CFU} / \mathrm{ml})$ used for the experiments. Statistical significance between the means $(n=8 \pm$ standard error) was calculated with the Student's $t$ test $(P \leq 0.05)$. All the experiments were conducted at least two times with similar results.

Seeds of Col-0, Tsu-1, and Van-1 were sown in a multiplant substrate (Terra do Paraíso, Holambra, SP) with vermiculite in a 5:2 (vol/vol) proportion. Plants were grown in a Conviron growth chamber, at $22^{\circ} \mathrm{C}, 60 \pm 5 \%$ relative humidity, and 12 -h photoperiod with light intensity of $100 \mu \mathrm{mol} \mathrm{m} \mathrm{m}^{-2} \mathrm{~s}^{-1}$. Plant inoculation was done according to the procedure described by Rogers (2012) with some modifications. Briefly, 4-week-old plants were used for inoculation and plants were not irrigated 1 day before and 1 day after the inoculation to optimize the inoculation efficiency. Four young, fully expanded rosette leaves were inoculated by dropping $5 \mu \mathrm{l}$ of the inoculum on the midrib at the petiole-leaf junction. The petiole tissue under the drop was pricked seven to eight times using an insulin needle $13 \mathrm{~mm} \times 0.38 \mathrm{~mm}$ (Becton Dickinson, Franklin Lakes, NJ). Water-inoculated plants were used as a mock control. Plants were kept well-watered during the experimental time.

$X$. fastidiosa subsp. pauca and X. fastidiosa subsp. fastidiosa detection. A total of 24 plants were inoculated with either water or bacterial inoculum from both strains. The tissue from rosette base was collected at 7, 14, and 21 days after inoculation (dai). DNA was extracted using the protocol developed by Doyle and Doyle (1990). DNA quality and quantity were determined by agarose gel electrophoresis and NanoDrop 8000 (Thermo Scientific, Waltham, MA), respectively. PCR-based diagnostic was done for both bacterial subspecies using the primers RST31 (5'-GCGTTAATTTTC GAAGTGATTCGATTGC-3') and RST33 (5'-CACCATTCGTA TCCCGGTG-3') as described by Minsavage et al. (1994). Two independent experiments were conducted with similar results.

To confirm the $X$. fastidiosa colonization, samples of the floral stem $0.5 \mathrm{~cm}$ above the rosette base were collected at 14 dai, immersed into Karnovsky buffer (Glutaraldehyde 2.5\%, Paraformaldehyde $2.5 \%$ in $0.1 \mathrm{M}$ sodium cacodylate buffer, $\mathrm{pH} 7.2$ ), and kept at $4^{\circ} \mathrm{C}$ for further evaluation using scanning electron microscope (SEM). Samples were cut with a microtome SM2010R (Leica, Wetzlar), immersed into the same buffer, and dehydrated for $10 \mathrm{~min}$ in each acetone solution of increasing concentration (50, 70, 90, 95, and 100\%). Subsequently, samples were dried in Balzers CPD030 desiccator, coated with gold using Balzers SCD050 sputter coater, and observed under a SEM (TM3000, Hitachi, Japan). Pictures were taken using the LAS X software (Leica) and analyzed in Adobe Photoshop CS6 (Adobe Systems, San Jose, CA).

For $X$. fastidiosa isolation, the rosette base of three plants containing the petioles were harvested and kept in a $15 \mathrm{ml}$ tube. Then, sample surface sterilization was processed in four steps: (i) rinsing with sterile water for $1 \mathrm{~min}$; (ii) rinsing with $70 \%$ ethanol for $2 \mathrm{~min}$; (iii) rinsing with $1 \%$ sodium hypochlorite for $2 \mathrm{~min}$; and (iv) washing twice with sterile and deionized water. Each rinsing step included vortexing and removing the solution before the next step. Surfacesterilized plant material was placed on a sterile Petri dish, sliced using a sterile scalpel, placed in a $2 \mathrm{ml}$ microtube, and homogenized in $1 \mathrm{ml}$ of PBS buffer using a sterile glass stirring rod and a vortex. Ten-fold serial dilutions of the homogenized suspension were diluted $1 \times 10^{-4}$ times by transferring $100 \mu \mathrm{l}$ of the homogenate to a new tube containing $900 \mu \mathrm{l}$ of PBS. Aliquots of $10 \mu \mathrm{l}$ of each dilution were plotted to either PW or buffered charcoal yeast extract (BCYE) solid medium (Wells et al. 1981); the plates were incubated at $28^{\circ} \mathrm{C}$ until the appearance of colonies (approximately 15 days). Colonies were identified as $X$. fastidiosa based on fastidious growth, coloring, and PCR using primers specific to X. fastidiosa (Minsavage et al. 1994).

Evaluation of $X$. fastidiosa colonization of Arabidopsis. A total of 48 plants were inoculated with either $X$. fastidios $a$ subsp. pauca or X. fastidiosa subsp. fastidiosa as described above and the presence of bacterial cells in systemic tissues were determined by qPCR. Rosette, floral stem ( $3 \mathrm{~cm}$ above the rosette base), and roots ( $3 \mathrm{~cm}$ below the rosette base) were harvested at 7, 14, and 21 dai and weighed to estimate the bacterial population by gram of tissue. qPCR reactions to detect $X$. fastidiosa subsp. pauca were setup in a total volume of $25 \mu \mathrm{l}$ containing $5 \mu \mathrm{l}$ of HOT FIREPol Probe qPCR Mix Plus (Solis BioDyne, Tartu, Estonia), $525 \mathrm{nM}$ of the primers CVC-1 (5'-AGATGA AAA CAATCATGC AAA-3') and CCSM-1 (5'-GCG CAT GCC AAG TCC ATA TTT-3'), 500 nM TAQCVC probe $\left(5^{\prime}-(6 \mathrm{FAM}) \mathrm{AAC}\right.$ CGC AGC AGA AGC CGC TCA TC (TAMRA)p-3') (Oliveira et al. 2002), and 200 ng of DNA template. qPCR reactions to detect $X$. fastidiosa subsp. fastidiosa were setup in a total volume of $25 \mu \mathrm{l}$ containing SsoAdvanced Universal Probes Supermix (Bio-Rad, Berkeley, CA), $0.4 \mu \mathrm{M}$ of the probe (5'TGGCAGGCAGCAACGATACGGCT-3') marked with FAM at the $5^{\prime}$-end and BHQ1 in the $3^{\prime}$-end (Sigma-Aldrich, St. Louis, MO), $0.2 \mu \mathrm{M}$ of primers HL5 (5'-AAGGCAATAAACGCGCACTA-3') and HL6 (5'-GGTTTTGCTGACTGGCAACA-3') (Francis et al. 2006), and 200 ng of DNA template. A negative control (DNA from mock-inoculated plants) and a positive control (bacteria genomic DNA) were included in all experiments. The amplification parameters were used according to Oliveira et al. (2002) $\left(50^{\circ} \mathrm{C}\right.$ for $2 \mathrm{~min}$, $95^{\circ}$ for $10 \mathrm{~min}$, followed by 40 cycles of $15 \mathrm{~s}$ at $95^{\circ} \mathrm{C}$ and $1 \mathrm{~min}$ at $60^{\circ} \mathrm{C}$ ) and capture of the signal was obtained in an ABI PRISM 7500 Sequence Detection System (Applied Biosystems, Foster City, CA). All samples were processed in duplicates (technical replicates) and the experiment was repeated at least twice (biological replicates) with similar results.

A standard curve for $X$. fastidiosa quantification was prepared using as a reference the molecular weight of 1 genome of $X$. fastidiosa that is equal to $2.94 \times 10^{-6} \mathrm{ng}$ (Muranaka et al. 2013; Guan et al. 2013). Considering that 1 genome corresponds to 1 cell, it is possible to estimate the number of cells according to the amount of $X$. fastidiosa DNA (e.g., $294 \mathrm{ng}$ corresponds to $1 \times 10^{8}$ cells). The standard curve was produced using known concentrations of genomic DNA of $X$. fastidiosa obtained from 10-fold serial dilutions from $1 \times 10^{-2}$ to $1 \times 10^{-8}$. DNA from $X$. fastidiosa was mixed with DNA of healthy Arabidopsis plants (100 $\mathrm{ng} / \mu \mathrm{l})$, aiming to simulate the natural conditions where the plant cells are infected with $X$. fastidiosa and DNA extraction is performed for diagnostic and bacterial quantifications (Muranaka et al. 2013; Guan et al. 2013). Table 1 shows the cycle threshold (Ct) obtained for each range point for each bacterium. The standard curve for $X$. fastidiosa subsp. pauca detection was $[y=-2.8607 x$ (DNA copy number) + $35.432]$ with $R^{2}=0.9944$ and the standard curve for $X$. fastidiosa 
subsp. fastidiosa detection was $[y=-3.3964 x$ (DNA copy number) +39.154$]$ with $R^{2}=0.9987$. Based on the comparison with controls, an increase in fluorescent signal below a threshold of 36 PCR cycles was considered positive (i.e., $\mathrm{Ct}<36$ ). Two independent experiments were performed with similar results and statistical significance among the means was calculated using analysis of variance (ANOVA) followed by Tukey's test $(P<0.05)$.

Confocal laser scanning microscopy (CLSM). X. fastidiosa subsp. fastidiosa-expressing green fluorescent protein (GFP) (Newman et al. 2003) was inoculated onto the midrib at the petiole-leaf junction in 4-week-old plants. A total of 152 transversal cross-sections were performed for 18 petioles at 7, 12, 17, 24, and 31 dai. Petiole cross-sections were observed under a TCS SPE CLSM (Leica) equipped with a $63 \times$ water-immersion objective and filter sets to detect fluorescent protein (GFP and CFP) and chlorophyll. Sequential scanning was conducted to avoid misinterpretations of overlapping fluorescent channels. Pictures were taken using a LAS X software (Leica) and analyzed in Adobe Photoshop CS6 (Adobe Systems, San Jose, CA).

Plant fresh and dry weight measurements. Fifteen plants were inoculated with either bacterium or water (mock control) as described above. Five weeks after inoculation, rosettes were harvested and immediately weighed. Subsequently, the same plants were dehydrated in an oven incubator set at $110^{\circ} \mathrm{C}$ for $20 \mathrm{~h}$ to obtain the dry weight. Two independent experiments were conducted, and statistical analysis was performed using ANOVA followed by Tukey's test $(P<0.05)$.

Anthocyanin detection assay. Arabidopsis plants were inoculated as described above and the floral stems were regularly cut at the base until the time for anthocyanin quantification. This procedure ensured the robustness of the assay. The amount of anthocyanin accumulated in inoculated leaves was determined according to Chen et al. (2013). Three to four leaves were frozen in liquid nitrogen and ground to a fine powder, followed by the addition of $1 \mathrm{ml}$ of methanol containing $1 \% \mathrm{HCl}$ and overnight incubation at $4^{\circ} \mathrm{C}$ in the dark. Anthocyanin was separated from organic elements and cell components by adding chloroform and centrifuged at $16,000 \times g$ for $10 \mathrm{~min}$. The aqueous phase of the supernatant was transferred to a new tube containing $1 \mathrm{ml}$ of $60 \%$ methanol $1 \% \mathrm{HCl}$ : $40 \%$ deionized water solution. The absorbance was measured at $530 \mathrm{~nm}$ for anthocyanin and at $657 \mathrm{~nm}$ for chlorophyll using a spectrophotometer (Spectronic 20, Bausch \& Lomb). The concentration of anthocyanin was determined according to the formula A530 nm - $(0.25 \times$ A657 nm)/g of fresh weight (Chen et al. 2013). Statistical significance among the means $(n=15$ in three biological replicates) was calculated with ANOVA and Tukey's test $(P<0.05)$.

\section{RESULTS}

X. fastidiosa subsp. pauca colonization of Arabidopsis ecotypes. Previous studies have demonstrated that different Arabidopsis ecotypes support variable population levels of $X$. fastidiosa

TABLE 1. Standard curves for Xylella fastidiosa subsp. pauca and X. fastidiosa subsp. fastidiosa detection by quantitative PCR in Arabidopsis thaliana

\begin{tabular}{|c|c|c|}
\hline & CVC-1/CCSM-1 & HL5/HL6 \\
\hline$X$. fastidiosa cells per reaction ${ }^{a}$ & $\begin{array}{c}\mathrm{Ct}^{\mathrm{b}}(X . \text { fastidiosa } \\
\text { subsp. pauca })\end{array}$ & $\begin{array}{l}\mathrm{Ct}^{\mathrm{b}}(X . \text { fastidiosa } \\
\text { subsp. fastidiosa })\end{array}$ \\
\hline $10^{8}$ & 13.2 & 12.0 \\
\hline $10^{7}$ & 15.4 & 15.0 \\
\hline $10^{6}$ & 17.6 & 19.1 \\
\hline $10^{5}$ & 20.9 & 22.1 \\
\hline $10^{4}$ & 23.6 & 25.9 \\
\hline $10^{3}$ & 27.1 & 29.0 \\
\hline $10^{2}$ & 30.1 & 32.1 \\
\hline
\end{tabular}

${ }^{a} X$. fastidiosa DNA were diluted in A. thaliana DNA extracts.

b Values represent the mean of three replicates. Cycle threshold $(\mathrm{Ct})>36$ is considered to be negative. subsp. fastidiosa Temecula-1 strain, where the ecotype Col-0 had the smallest bacterial population and Tsu-1 was the most susceptible ecotype (Rogers 2012). Thus, we verified whether the $X$. fastidiosa subsp. pauca 9 a $5 \mathrm{c}$ strain also shows similar trends in bacterial growth within the ecotypes Col-0, Tsu-1, and Van- 0 . We observed that $X$. fastidiosa subsp. pauca is able to efficiently survive at a high level in all ecotypes (Fig. 1A). Interestingly, unlike X. fastidiosa subsp. fastidiosa (Rogers 2012), X. fastidiosa subsp. pauca population was significantly higher (2- to 10-fold) in Col-0 compared with its survival in the other ecotypes (Fig. 1A). To verify whether this apparently contrasting result was due the different inoculum concentration used in both experiments (i.e., 0.2 OD $_{600 \mathrm{~nm}}$ used by Rogers (2012) and $0.7 \mathrm{OD}_{600 \mathrm{~nm}}$ used in this study), we repeated the experiment with several inoculum concentrations $(0.2,0.7$, and 2.0). X. fastidiosa subsp. pauca colonization of Col-0 does not differ in response to inoculation dose as we detected similar amounts of bacterial cells from all tissue samples (Fig. 1B). In fact, the inoculum OD is very dependent of the time of bacteria growth on the plate. In this study, we used bacteria that grew from 5 to 6 days on solid media, otherwise the amount of exopolysaccharide produced by old cells can mask the real number of living cells in OD measurement and generate not reproducible results after plant inoculation. Altogether, these results indicate that Col-0 is a good reference ecotype to study $X$. fastidiosa subsp. pauca colonization of plants and it was chosen for further analyses.

$X$. fastidiosa subsp. pauca and $X$. fastidiosa subsp. fastidiosa colonization of Col-0. Next, we compared $X$. fastidiosa subsp. pauca and $X$. fastidiosa subsp. fastidiosa inoculation efficiencies in Col-0 to verify whether the behavior of these bacteria differ in our experimental setup. Indeed, X. fastidiosa subsp. pauca was more able to infect Col-0 than $X$. fastidiosa subsp. fastidiosa as the index of detection for these bacteria was 80 to $100 \%$ and 50 to $80 \%$, respectively, during time course of colonization (Fig. 2A and B). This result is in agreement with the findings reported by Rogers (2012).

To rule out the possibility that the positive detection of bacteria was due to survival of bacterial cells from the inoculum, the detection analysis was performed in distant tissues using SEM. As this analysis was performed using tissue above the rosette base, we confirmed that plants positive for colonization was a consequence of the movement of the bacteria in the xylem. SEM revealed that $X$. fastidiosa subsp. pauca cells colonized the xylem stem above the rosette base at 14 dai (Fig. 2C). In addition, bacterial isolation in BCYE medium at 7 and 21 dai confirmed that those were living cells $\left(2.7 \times 10^{6} \mathrm{CFU} / \mathrm{g}\right.$ of tissue; $\left.\mathrm{SE}= \pm 2.2 \times 10^{5}\right)$.

$X$. fastidiosa subsp. pauca and $X$. fastidiosa subsp. fastidiosa systemically colonize Col-0. It is well-known that
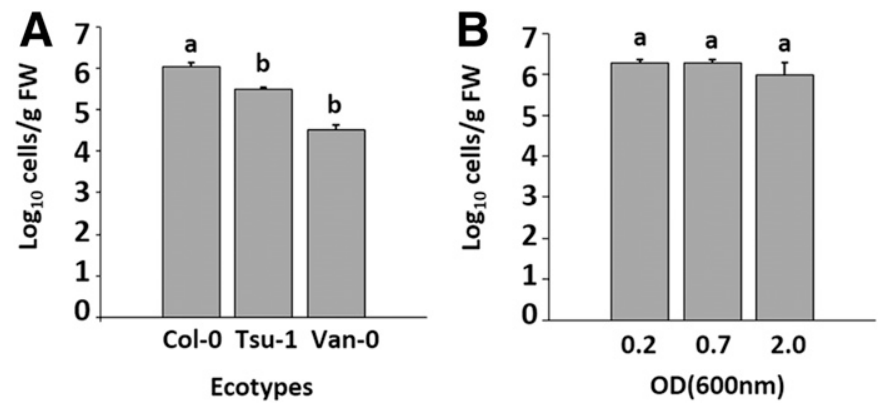

Fig. 1. Colonization of Arabidopsis ecotypes by Xylella fastidiosa subsp. pauca. A, Evaluation of X. fastidiosa subsp. pauca population in three different ecotypes $\left(\mathrm{OD}_{600 \mathrm{~nm}}=0.7\right)$. B, X. fastidiosa subsp. pauca population in Col-0 is not affected by different concentration of inoculum. Results in the graphs are shown as means of two independent biological replicates $(n=12) \pm$ standard error (SE). Statistical difference among the means of different genotypes was determined by analysis of variance followed by Tukey's test $(P \leq$ $0.05) . \mathrm{FW}=$ fresh weight. $\mathrm{OD}=$ optical density. 
$X$. fastidiosa spp. are able to systemically colonize susceptible hosts such as citrus, grapevine, and olive trees (Newman et al. 2003; Niza et al. 2015; Saponari et al. 2017). Thus, to verify whether $X$. fastidiosa subsp. pauca and $X$. fastidiosa subsp. fastidiosa can also colonize Col-0 systemically, we enumerated the bacterial population in different parts of the plant during the time course of colonization. As expected, a large bacterial population was observed in the rosette base, which is the sample closest to the inoculation point. At this region, X. fastidiosa subsp. pauca population remained at the same level (6 logs) (Fig. 3A), while the $X$. fastidiosa subsp. fastidiosa population ranged from 5 to 6 $\operatorname{logs}$ throughout the experimentation time (Fig. 3C). The bacterial population in the floral stem was of similar size for both strains (4 to $5 \operatorname{logs}$ ), but significant variation during the time course of colonization was observed to $X$. fastidiosa subsp. fastidiosa (Fig. $3 \mathrm{~A}$ and $\mathrm{C}$ ). No variation in bacterial population sizes in roots was observed along the time course of colonization; however, the population of $X$. fastidiosa subsp. pauca was 10 times larger than that of $X$. fastidiosa subsp. fastidiosa. These results demonstrate that Col-0 can be colonized systemically by both strains of $X$. fastidiosa as bacteria were found in all distant tissues analyzed (i.e., rosette base, floral stems, and roots [Fig. 3]). An illustration of the plant tissues used for the experiments is shown in Figure 3B.

$X$. fastidiosa subsp. fastidiosa moves against the xylem net flow in Col-0 petioles. As $X$. fastidiosa subsp. fastidiosa is able to move against the xylem net flow in its grapevine host (Meng et al. 2005; Li et al. 2007), we sought to evaluate whether $X$. fastidiosa subsp. fastidiosa have the same behavior in Col-0. Petioles were inoculated with $X$. fastidiosa subsp. fastidiosa-GFP (Newman et al. 2003) and subsequently cut into a series of transversal sections at 7, 12, 17, 24, and 31 dai (Fig. 4A). Overall, the bacterial population increased during the time course of colonization as the green fluorescence from the bacterium in the xylem bundles increased over time (Fig. 4C). At 7 dai, we detected $X$. fastidiosa subsp. fastidiosa until the fourth section and at 17 dai, we detected the bacterium at the ninth section (Fig. 4C). From 24

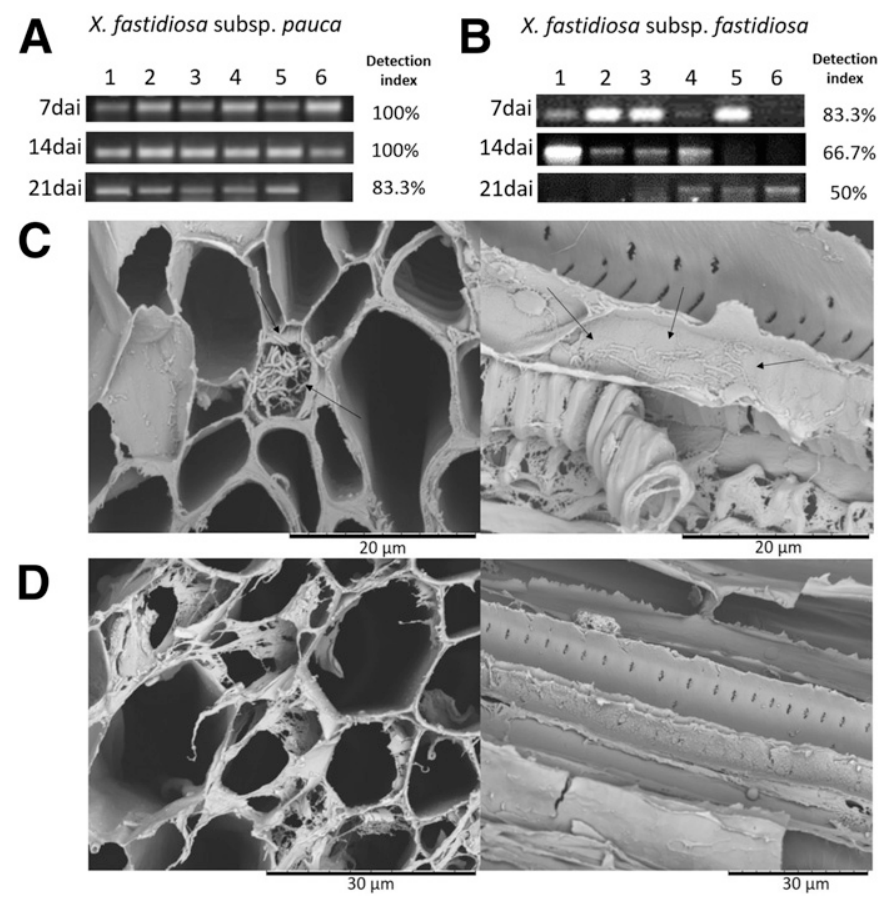

Fig. 2. Xylella fastidiosa colonizes Col-0. Detection of $X$. fastidiosa subspecies A, pauca and B, fastidiosa in Col-0 by PCR at 7, 14, and 21 days after inoculation (dai). C, Scanning electron micrographs showing the presence of $X$. fastidiosa in xylem vessels of Col-0 floral stem at 14 dai in transversal (left) and longitudinal (right) sections. D, Micrographs of floral stem of mockinoculated plants. to 31 dai, the bacterial population increased dramatically as visualized by the intense green fluorescence in the xylem bundles (Fig. 4C), which is characteristic of biofilm formation (Newman et al. 2003). X. fastidiosa subsp. fastidiosa migration in the xylem of the petiole followed the Arabidopsis xylem organization (Nieminen et al. 2004) (Fig. 4B), which was found inside some vessels of the lateral bundles from 7 to 24 dai, but also colonizing the entire central bundle at 31 dai (Fig. 4C). These results confirm that $X$. fastidiosa subsp. fastidiosa is able to move and colonize the xylem bundles of the petiole and reach the xylem of the rosette base of Col-0. Bacterial population size was also quantified by qPCR at 35 dai $\left(4.4 \times 10^{7}\right.$ cells $/ g$ of tissue; $\left.\mathrm{SE}= \pm 6 \times 10^{6}\right)$.

$X$. fastidiosa subsp. pauca and $X$. fastidiosa subsp. fastidiosa induce anthocyanin accumulation in Col-0 leaves. In order to identify plant phenotypes associated with $X$. fastidiosa colonization, we measured the dry matter content (DMC) of bacterial- and mock-inoculated plants. However, we have not observed differences among the treatments (Fig. 5A). Interestingly, we noticed an increased purpling in bacterial-inoculated leaves compared with mock control (Fig. 5B). Thus, we designed experiments to identify the best conditions to obtain reproducible results with potential to use anthocyanin accumulation as a phenotypic marker for $X$. fastidiosa colonization of Arabidopsis. First, we verified a consistent anthocyanin accumulation in leaves inoculated with either X. fastidiosa subsp. pauca or X. fastidiosa subsp. fastidiosa (Fig. 5B) compared with mock control when the floral stem (or its regrowth) of the plant was removed. Second, purpling of the infected leaves, indicative of anthocyanin accumulation in this tissue, occurred as early as 1 week after inoculation. The variation in purpling timing depended upon slight variations in bacterial inoculum concentration, plant developmental stage, and environmental conditions. Third, quantification of anthocyanin accumulation in these leaves revealed that bacterium-inoculated leaves contained a significantly higher amount of anthocyanin than the mock-inoculated leaves (Fig. 5B). Following this procedure, the accumulation of anthocyanin proved to be a reliable and quantifiable phenotype to assess Col-0 colonization by both strains of $X$. fastidiosa.

\section{DISCUSSION}

Until very recently, $X$. fastidiosa subsp. pauca had been found only in Latin America causing diseases mainly in citrus and coffee in Brazil (Coletta-Filho et al. 2017). However, recent detection of $X$. fastidiosa subsp. pauca in some European countries including serious damages in olive trees in Italy underscores the need for developing alternative model host for this subspecies to advance knowledge on this pathosystem. Thus, in this study we focused on Arabidopsis, as it was previously demonstrated to be a suitable host for X. fastidiosa subsp. fastidiosa (Rogers 2012) and the welldocumented genetic basis for its interaction with pathogens (Windram et al. 2012; Zhang et al. 2017).

We verified that, different from what was observed for $X$. fastidiosa subsp. fastidiosa (Rogers 2012), the best ecotype for $X$. fastidiosa subsp. pauca is Col-0 as the bacterial population was significantly higher than the Tsu- 1 and Van-0 ecotypes independently of the inoculum concentration (Fig. 1). Subsequently, we observed that the efficiency of inoculation in Col-0 was higher to $X$. fastidiosa subsp. pauca (80\%) compared with $X$. fastidiosa subsp. fastidiosa (50\%) (Fig. 2). These results suggest that $X$. fastidiosa subspecies might have different behavior in Arabidopsis ecotypes. Nevertheless, when bacterial populations were analyzed in different parts of the plant (xylem of rosette base, floral stem, and roots) both subspecies were able to systemically colonize Col-0. As expected, the bacterial population was higher in the rosette base, which is the closest to the inoculation point, than that of other parts of the plant; however, the X. fastidiosa subsp. fastidiosa population decreased significantly during the time course 
of colonization in rosette base and floral stem whereas $X$. fastidiosa subsp. pauca population remained constant (Fig. 3). One could infer that resistance response in Col-0 could be more efficient toward $X$. fastidiosa subsp. fastidiosa than to $X$. fastidiosa subsp. pauca.

$X$. fastidiosa subsp. fastidiosa bacterial population increased in the entire petiole during colonization (Fig. 4). For instance, small cell aggregates were observed only at the point closest to the inoculation site at 7 dai. The entire petiole was colonized after 17 dai and by 24 dai, extensive colonization with biofilm-like structures in the xylem was observed in all petiole sections (Fig. 4). This finding demonstrates that $X$. fastidiosa subsp. fastidiosa moves against the water flow in the xylem to colonize distant tissues. As the pathogenicity of $X$. fastidiosa is associated with its capacity to move and systemically colonize the plant host (Caserta et al. 2017; Chatterjee et al. 2008; De La Fuente et al. 2013), our data suggest that Col-0 is a host for $X$. fastidiosa and these phenotypes can be easily used to test mutants of specific genes in Col-0 that could be associated to $X$. fastidiosa interaction.

Although the bacterial movement and colonization are excellent phenotypes to evaluate Col-0 mutants or to screen for strains of $X$. fastidiosa with different level of virulence, we sought to establish a quick visual tool to facilitate phenotyping of infected plants. Following this concept, we investigated some phenotypes that could be associated to $X$. fastidiosa colonization of Arabidopsis. During
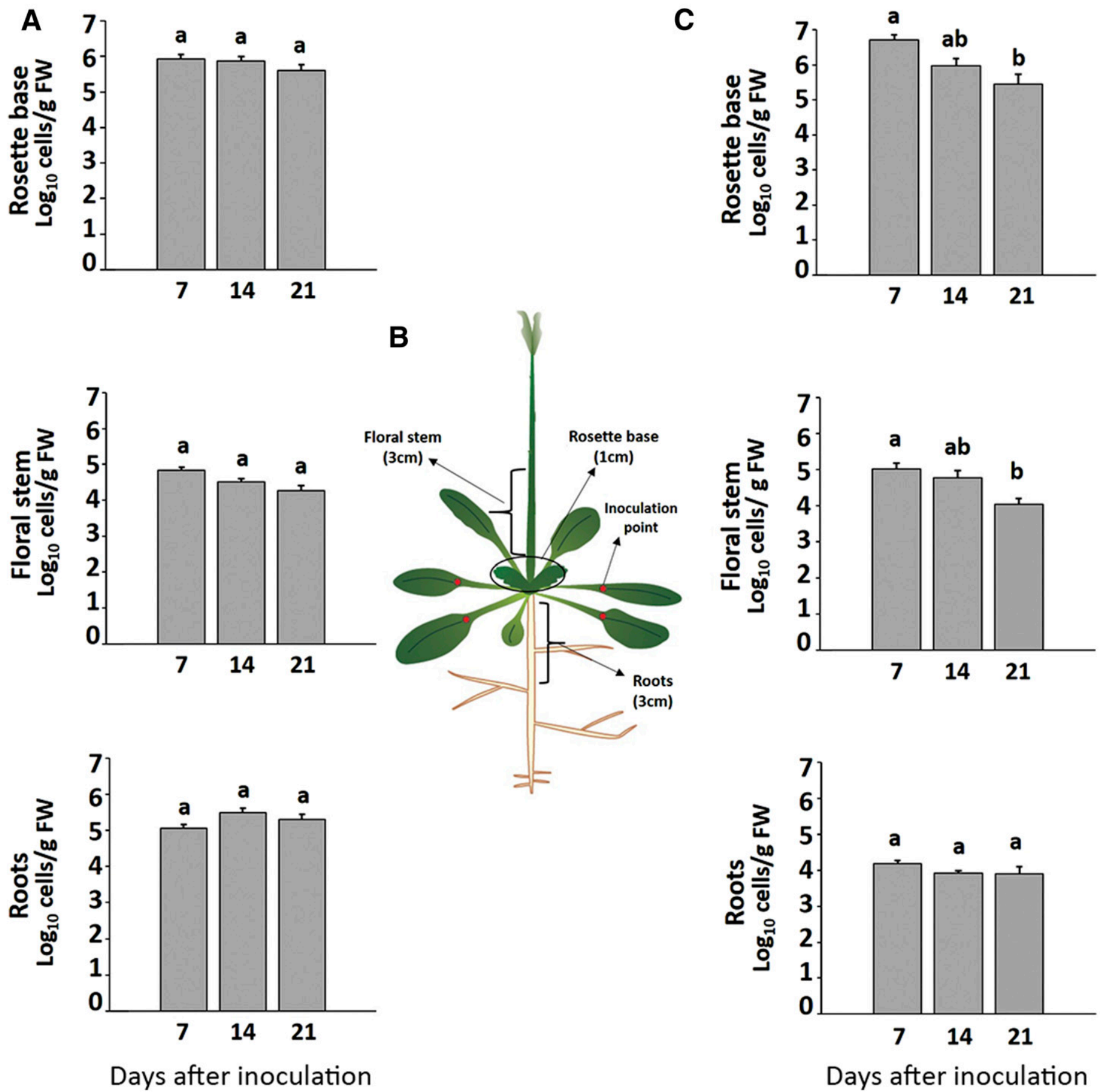

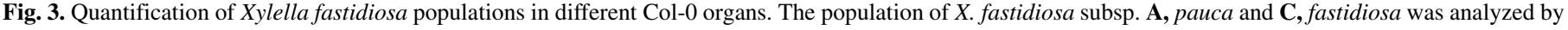

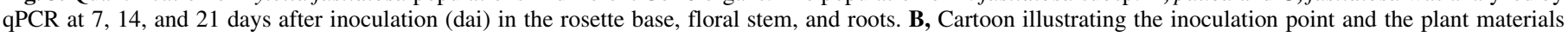

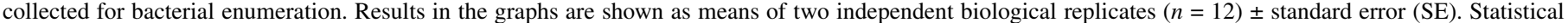
difference among the means of different genotypes was determined by analysis of variance followed by Tukey's test $(P \leq 0.05)$. FW $=$ fresh weight. 
the course of experimentation, we observed that only inoculated plants with the two subspecies of $X$. fastidiosa showed purpling in the inoculated leaves, characteristic of anthocyanin accumulation (Fig. 5) (Himeno et al. 2014). These symptoms were more evident when the floral stems were clipped off from the rosette. Using this procedure, the anthocyanin accumulation was significantly and consistently higher in inoculated leaves. In addition, both X. fastidiosa subsp. pauca and $X$. fastidiosa subsp. fastidiosa induced similar anthocyanin accumulation response. Curiously, anthocyanin accumulation is a characteristic symptom in phytoplasma-infected plants (Lee et al. 2000). Phytoplasma shares some similarities with $X$. fastidiosa as they are both plant-pathogenic bacteria that inhabit the vascular system (Phytoplasma in the phloem and X. fastidiosa in the xylem) and are transmitted by insect vectors (Oshima et al. 2013). Using anthocyanindeficient Arabidopsis mutants, it has been demonstrated that anthocyanin accumulation is associated with reduction of leaf cell death caused by phytoplasma colonization, indicating that anthocyanin accumulation might be important for phytoplasm survival (Himeno et al. 2014). In addition, other studies have shown that plant immune responses repress anthocyanin biosynthesis in order to activate plant defenses against bacterial or fungi pathogens (Mclusky et al. 1999; Schenke et al. 2011; Serrano et al. 2012). Studies involving Arabidopsis immune responses also have shown that synthetic immune-elicitor such as flg22 and EF-Tu repress anthocyanin accumulation (Schenke et al. 2011; Serrano et al. 2012). In addition,

A

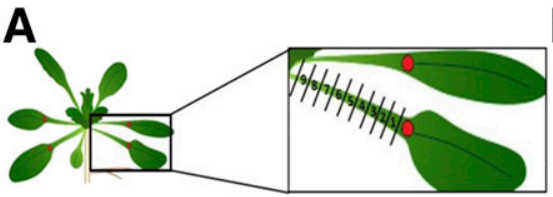

C

7 dai

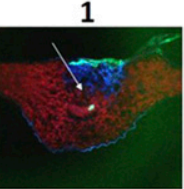

1
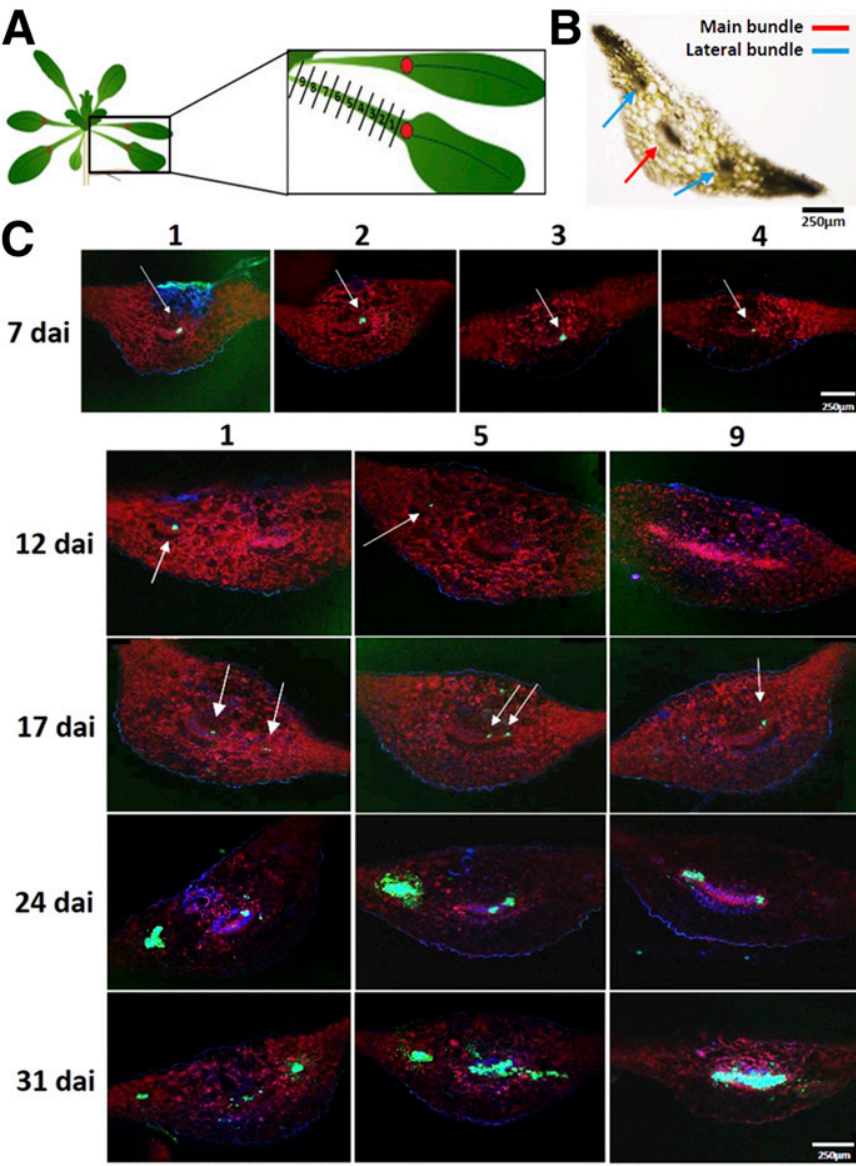

3
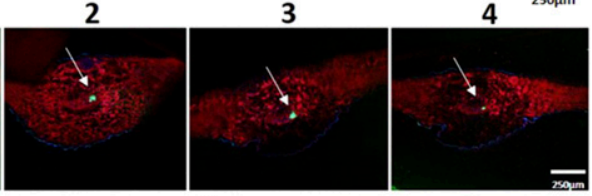

9

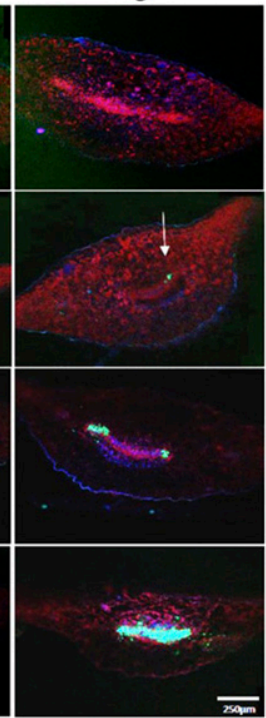

Fig. 4. Temporal movement of Xylella fastidiosa subsp. fastidiosa in Col0 petioles analyzed by confocal laser scanning microscopy. A, Cartoon illustrating the petiole sections used to analyze the bacterial migration out of the inoculation point (red circle). B, Micrograph showing the vascular tissue organization in Arabidopsis petioles. C, Representative micrographs of transversal sections of the petioles showing green fluorescence from $X$. fastidiosaGFP inside the xylem bundles, the arrows point to fluorescent bacterial cells. Number on the top of the pictures correspond to the sections in panel A. dai = days after inoculation. it is known that $A$. thaliana grown in low phosphorus $(\mathrm{P})$ conditions increases anthocyanin content (Sanchez-Calderón et al. 2006) and $X$. fastidiosa infection causes $\mathrm{P}$ deficiency in many crops (Andersen and French 1987; De La Fuente at al. 2013; Silva-Stenico et al. 2009). These facts lead us to speculate that $\mathrm{P}$ deficiency could also occur in A. thaliana infected with $X$. fastidiosa and as a consequence inducing anthocyanin accumulation. Nevertheless, the role of anthocyanin accumulation in Arabidopsis-X. fastidiosa interactions needs to be further investigated.

There is a large body of literature regarding putative candidate genes involved in resistance or susceptibility of well-established crop hosts against $X$. fastidiosa (Chakraborty et al. 2016; De Souza et al. 2007; Giampetruzzi et al. 2016; Lin et al. 2007; Parker et al. 2016; Rodrigues et al. 2013; Sabella et al. 2018; Yang et al. 2011). For instance, it has been shown that genes involved with $X$. fastidiosa subsp. fastidiosa movement and biofilm formation, important for bacterial pathogenicity, are induced in the presence of calcium (Parker et al. 2016). Moreover, genes encoding calcium transporters are significantly induced in the susceptible plant Olea europaea 'Ogliarola salentina' infected with $X$. fastidiosa subsp. pauca (Giampetruzzi et al. 2016), suggesting that calcium may contribute to $X$. fastidiosa colonization. However, there is no report on the functional analysis of these genes in the host plant to validate this hypothesis. In addition, some genetic mechanisms have been suggested as being involved with resistance to $X$. fastidiosa, for example the activation of pattern-recognition receptors, which recognize pathogen-associated molecular patterns and trigger cell defense responses (Magalhães et al. 2016; Rapicavoli et al. 2018). The induction of members of these receptors was found in the resistant and tolerant hosts for X. fastidiosa subsp. pauca; Citrus reticulata 'Ponkan' (Rodrigues et al. 2013) and Olea europaea 'Leccino' (Giampetruzzi et al. 2016), respectively, and in the moderately tolerant host Vitis vinifera 'Thompson Seedless' (Wallis and Chen 2012) in response to $X$. fastidiosa subsp. fastidiosa
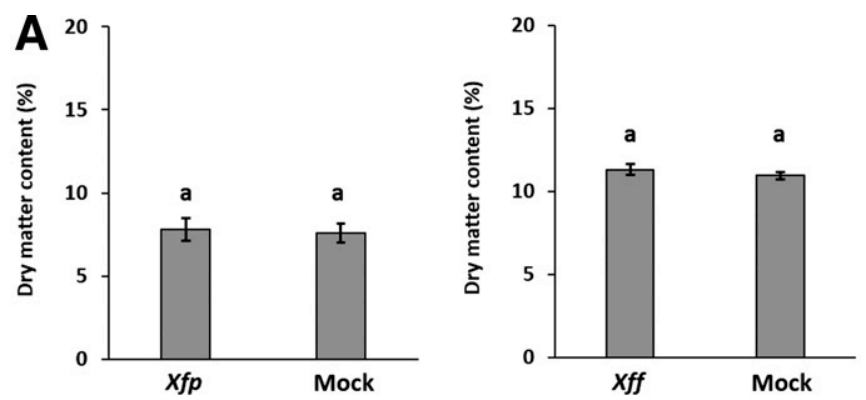

B
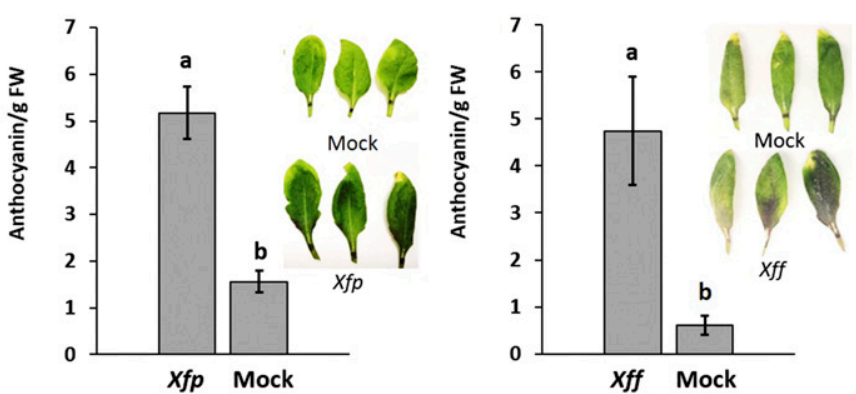

Fig. 5. Dry matter content and anthocyanin accumulation in Col-0 inoculated leaves. A, Percentage of dry matter content and $\mathbf{B}$, anthocyanin accumulation of plants inoculated with Xylella fastidiosa subsp. pauca (on the left) or $X$. fastidiosa subsp. fastidiosa (on the right). Pictures were taken at 3 weeks after inoculation with X. fastidiosa subsp. pauca or X. fastidiosa subsp. fastidiosa and water (Mock). Results in the graphs are shown as means of two independent biological replicates $(n=20) \pm$ standard error $($ SE). Statistical difference among the means was determined by analysis of variance followed by Tukey's test $(P \leq 0.05)$. 
colonization (Chakraborty et al. 2016). It is important to note that the identified candidate genes in these pathosystems have high similarity to leucine-rich repeat receptor-like kinases (LRR-RLKs) from different plant species, including Arabidopsis (Magalhães et al. 2016). In addition, induction of genetic mechanism involved in cell wall lignification is associated with impaired $X$. fastidiosa colonization in resistant or tolerant varieties (Giampetruzzi et al. 2016; Niza et al. 2015; Rodrigues et al. 2013; Sabella et al. 2018). These are only a few examples of genes or genetic mechanisms involved in $X$. fastidiosa susceptibility or resistance already identified for this widespread phytopathogen with no functional validation of the genes involved. The lack of a tractable genetic system has been a bottleneck to advance functional analysis to demonstrate the possible role of these genes in plant immune response to $X$. fastidiosa in a timely manner.

It was previously demonstrated that Arabidopsis could be an alternative host for $X$. fastidiosa subsp. fastidiosa (Rogers 2012); however, this model plant has not been used to study key genes associated to plant $-X$. fastidiosa interactions, despite of the extensive use of Arabidopsis to improve the knowledge of genetic mechanisms for many other phytopathogens (Panchal et al. 2016; Windram et al. 2012; Witzel et al. 2015). The experimental conditions used before by Rogers (2012) has not allowed for the discovery of the phenotypes we identified, highlighting the importance of defining detailed protocols to capitalize on the Arabidopsis resources. With some modifications in the experimental procedure, we showed that Col-0 is a useful host for both X. fastidiosa subsp. pauca and X. fastidiosa subsp. fastidiosa where systemic colonization, bacterial movement, and anthocyanin accumulation are reproducible phenotypes that can be used to uncover the knowledge of genetic mechanisms involved in Xylella-plant interaction.

\section{LITERATURE CITED}

Almeida, R. P. P., and Nunney, L. 2015. How do plant diseases caused by Xylella fastidiosa emerge? Plant Dis. 99:1457-1467.

Almeida, R. P. P., Pereira, E. F., Purcell, A. H., and Lopes, J. R. S. 2001. Multiplication and movement of a citrus strain of Xylella fastidiosa within sweet orange. Plant Dis. 85:382-386.

Alonso, J. M., Stepanova, A. N., Leisse, T. J., Kim, C. J., Chen, H., Shinn, P., Stevenson, D. K., Zimmerman, J., Barajas, P., Cheuk, R., Gadrinab, C., Heller, C., Jeske, A., Koesema, E., Meyers, C. C., Parker, H., Prednis, L., Ansari, Y., Choy, N., Deen, H., Geralt, M., Hazari, N., Hom, E., Karnes, M., Mulholland, C., Ndubaku, R., Schmidt, I., Guzman, P., Aguilar-Henonin, L., Schmid, M., Weigel, D., Carter, D. E., Marchand, T., Risseeuw, E., Brogden, D., Zeko, A., Crosby, W. L., Berry, C. C., and Ecker, J. R. 2003. Genome-wide insertional mutagenesis of Arabidopsis thaliana. Science 301:653-657.

Andersen, P. C., and French, W. J. 1987. Biophysical characteristics of peach trees infected with phony peach disease. Physiol. Mol. Plant Pathol. 31:25-40.

Baccari, C., and Lindow, S. 2010. Assessment of the process of movement of Xylella fastidiosa within susceptible and resistant grape cultivars. Phytopathology 101:77-84.

Bové, J. M., and Ayres, A. J. 2007. Etiology of three recent diseases of citrus in São Paulo State: Sudden death, variegated chlorosis and Huanglongbing. IUBMB Life 59:346-354.

Caserta, R., Souza-Neto, R. R., Takita, M. A., Lindow, S. E., and De Souza, A. A. 2017. Ectopic expression of Xylella fastidiosa rpff conferring production of diffusible signal factor in transgenic tobacco and citrus alters pathogen behavior and reduces disease severity. Mol. Plant-Microbe Interact. 30:866-875.

Chakraborty, S., Nascimento, R., Zaini, P. A., Gouran, H., Rao, B. J., Goulart, L. R., and Dandekar, A. M. 2016. Sequence/structural analysis of xylem proteome emphasizes pathogenesis-related proteins, chitinases and $\beta-1,3-$ glucanases as key players in grapevine defense against Xylella fastidiosa. PeerJ 4:e2007.

Chatterjee, S., Almeida, R. P., and Lindow, S. 2008. Living in two worlds: The plant and insect lifestyles of Xylella fastidiosa. Annu. Rev. Phytopathol. 46: 243-271.

Chen, M., Zhang, W. H., Lv, Z. W., Zhang, S. L., Hidema, J., Shi, F. M., and Liu, L. L. 2013. Abscisic acid is involved in the response of Arabidopsis mutant sad2-1 to ultraviolet-B radiation by enhancing antioxidant enzymes. Science 85:79-86.
Clough, S. J., and Bent, A. F. 1998. Floral dip: A simplified method for Agrobacterium-mediated transformation of Arabidopsis thaliana. Plant $\mathrm{J}$. 16:735-743.

Coletta-Filho, H. D., Francisco, C. S., Lopes, J. R., Muller, C., and Almeida, R. P. 2017. Homologous recombination and Xylella fastidiosa host-pathogen associations in South America. Phytopathology 107:305-312.

Coletta-Filho, H. D., Pereira, E. O., Souza, A. A., Takita, M. A., Cristofani-Yale, M., and Machado, M. A. 2007. Analysis of resistance to Xylella fastidiosa within a hybrid population of Pera sweet orange $\times$ Murcott tangor. Plant Pathol. 56:661-668.

Davis, M. J., French, W. J., and Schaad, N. W. 1981. Axenic culture of the bacteria associated with phony disease of peach and plum leaf scald. Curr. Microbiol. 6:309-314.

De La Fuente, L., Parker, J. K., Oliver, J. E., Granger, S., Brannen, P. M., van Santen, E., and Cobine, P. A. 2013. The bacterial pathogen Xylella fastidiosa affects the leaf ionome of plant hosts during colonization. PLoS One 8:e62945.

De Souza, A. A., Takita, M. A., Coletta-Filho, H. D., Campos, M. A., Teixeira, J. E. C., Targon, M. L. P. N., Carlos, E. F., Ravasi, J. F., Fischer, C. N., and Machado, M. A. 2007. Comparative analysis of differentially expressed sequence tags of sweet orange and mandarin infected with Xylella fastidiosa. Genet. Mol. Biol. 30:965-971.

Doyle, J. J., and Doyle, J. L. 1990. Isolation of plant DNA from fresh tissue. Focus 12:13-15.

Francis, M., Lin, H., Cabrera-La Rosa, J., Doddapaneni, H., and Civerolo, E. L. 2006. Genome-based PCR primers for specific and sensitive detection and quantification of Xylella fastidiosa. Eur. J. Plant Pathol. 115:203-213.

Fry, S. M., and Milholland, R. D. 1990. Multiplication and translocation of Xylella fastidiosa in petioles and stems of grapevines resistant, tolerant and susceptible to Pierce's disease. Phytopathology 80:61-65.

Giampetruzzi, A., Morelli, M., Saponari, M., Loconsole, G., Chiumenti, M., Boscia, D., Savino, V. N., Martelli, G. P., and Saldarelli, P. 2016. Transcriptome profiling of two olive cultivars in response to colonization by the CoDiRO strain of Xylella fastidiosa subsp. pauca. BMC Genomics 27:17: 475.

Guan, W., Shao, J., Singh, R., Davis, R. E., Zhao, T. C., and Huang, Q. 2013. A TaqMan-based real time PCR assay for specific detection and quantification of Xylella fastidiosa strains causing bacterial leaf scorch in oleander. J. Microbiol. Methods 92:108-112.

Himeno, M., Kitazawa, Y., Yoshida, T., Maejima, K., Yamaji, Y., Oshima, K., and Namba, S. 2014. Purple top symptoms are associated with reduction of leaf cell death in phytoplasma-infected plants. Sci. Rep. 4:1-7.

Lee, I. M., Davis, R. E., and Gundersen-Rindal, D. E. 2000. Phytoplasma: Phytopathogenic mollicutes. Annu. Rev. Microbiol. 54:221-255.

Li, Y., Hao, G., Galvani, C. D., Meng, Y., De La Fuente, L., Hoch, H. C., and Burr, T. J. 2007. Type I and type IV pili of Xylella fastidiosa affect twitching motility, biofilm formation and cell-cell aggregation. Microbiology 153:719-726.

Lin, H., Doddapaneni, H., Takahashi, Y., and Walker, M. A. 2007. Comparative analysis of ESTs involved in grape responses to Xylella fastidiosa colonization. BMC Plant Biol. 22:7-8.

Luvisi, A., Aprile, A., Sabella, E., Vergine, M., Nicolì, F., Nutricati, E., Miceli, A., Negro, C., and De Bellis, L. 2017b. Xylella fastidiosa subsp. pauca (CoDiRO strain) colonization in four olive (Olea europaea L.) cultivars: Profile of phenolic compounds in leaves and progression of leaf scorch symptoms. Phytopathol. Mediterr. 56:259-273.

Luvisi, A., Nicolì, F., and De Bellis, L. 2017a. Sustainable management of plant quarantine pests: the case of olive quick decline syndrome. Sustainability $9: 1-19$.

Magalhães, D. M., Scholte, L. L., and Silva, N. V. 2016. LRR-RLK family from two Citrus species: Genome-wide identification and evolutionary aspects. BMC Genomics 17:623.

Mang, S. M., Frisullo, S., Elshafie, H. S., and Camele, I. 2016. Diversity evaluation of Xylella fastidiosa from infected olive trees in Apulia (Southern Italy). Plant Pathol. J. 32:102-111.

Mclusky, S. R., Bennett, M. H., Beale, M. H., Lewis, M. J., Gaskin, P., and Mansfield, J. W. 1999. Cell wall alterations and localized accumulation of feruloyl-3'-methoxytyramine in onion epidermis at sites of attempted penetration by Botrytis allii are associated with actin polarisation, peroxidase activity and suppression of flavonoid biosynthesis. Plant J. 17:523-534.

Mencuccini, M., Micheli, M., Angiolillo, A., and Baldoni, L. 1999. Genetic transformation of olive (Olea europaeae L.) using Agrobacterium tumefaciens. Acta Hortic.: 515-520.

Meng, Y., Li, Y., Galvani, C. D., Hao, G., Turner, J. N., Burr, T. J., and Hoch, H. C. 2005. Upstream migration of Xylella fastidiosa via pilus-driven twitching motility. J. Bacteriol. 187:5560-5567.

Minsavage, G. V., Thompson, C. M., Hopkins, D. L., Leite, R. M. V. B. C., and Stall, R. E. 1994. Development of a polymerase chain reaction protocol for detection of Xylella fastidiosa in plant tissue. Phytopathology 84:456-461. 
Muranaka, L. S., Giorgiano, T. E., and Takita, M. A. 2013. N-Acetylcysteine in Agriculture, a novel use for an old molecule: Focus on controlling the plant-pathogen Xylella fastidiosa. PLoS One 8:e72937.

Newman, K. L., Almeida, R. P. P., Purcell, A. H., and Lindow, S. E. 2003. Use of a green fluorescent strain for analysis of Xylella fastidiosa colonization of Vitis vinifera. Appl. Environ. Microbiol. 69:7319-7327.

Nieminen, K. M., Kauppinen, L., and Helariutta, Y. 2004. Update on xylem development a weed for wood? Arabidopsis as a genetic model. Plant Physiol. 135:653-659.

Niza, B., Coletta-Filho, H. D., Merfa, M. V., Takita, M. A., and De Souza, A. A. 2015. Differential colonization patterns of Xylella fastidiosa infecting citrus genotypes. Plant Pathol. 64:1259-1269.

Oliveira, A. C., Vallim, M. A., Semighini, C. P., Araújo, W. L., Goldman, G. H., and Machado, M. A. 2002. Quantification of Xylella fastidiosa from citrus trees by real-time polymerase chain reaction assay. Phytopathology 92:1048-1054.

Oshima, K., Maejima, K., and Namba, S. 2013. Genomic and evolutionary aspects of phytoplasmas. Front. Microbiol. 4:230.

Panchal, S., Roy, D., Chitrakar, R., Price, L., Breitbach, Z. S., Armstrong, D. W., and Melotto, M. 2016. Coronatine facilitates Pseudomonas syringae infection of Arabidopsis leaves at night. Front. Plant Sci. 7:1-11.

Parker, J. K., Chen, H., McCarty, S. E., Liu, L. Y., and De La Fuente, L. 2016. Calcium transcriptionally regulates the biofilm machinery of Xylella fastidiosa to promote continued biofilm development in batch cultures. Environ. Microbiol. 18:1620-1634.

Peña, L., Martín-Trillo, M., Juárez, J., Pina, J., Navarro, L., and Martínez-Zapater, J. M. 2001. Constitutive expression of Arabidopsis LEAFY or APETALA1 genes in citrus reduces their generation time. Nat. Biotechnol. 19:263-267.

Rapicavoli, J. N., Blanco-Ulate, B., Muszyński, A., Figueroa-Balderas, R., Morales-Cruz, A., Azadi, P., Dobruchowska, J. M., Castro, C., Cantu, D., and Roper, M. C. 2018. Lipopolysaccharide O-antigen delays plant innate immune recognition of Xylella fastidiosa. Nat. Commun. 9:390.

Rodrigues, C. M., De-Souza, A. A., Takita, M. A., Kishi, L. T., and Machado, M. A. 2013. RNA-Seq analysis of Citrus reticulata in the early stages of Xylella fastidiosa colonization reveals auxin-related genes as a defense response. BMC Genomics 14:676.

Rogers, E. E. 2012. Evaluation of Arabidopsis thaliana as a model host for Xylella fastidiosa. Mol. Plant-Microbe Interact. 25:747-754.

Sabella, E., Luvisi, A., Aprile, A., Negro, C., Vergine, M., Nicolì, F., Miceli, A., and De Bellis, L. 2018. Xylella fastidiosa induces differential expression of lignification related-genes and lignin accumulation in tolerant olive trees cv. Leccino. J. Plant Physiol. 220:60-68.

Sanchez-Calderón, L. S., López-Bucio, J., Chacón-López, A., Gutiérrez-Ortega, A., Hernández-Abreu, E., and Herrera-Estrella, L. 2006. Characterization of low phosphorus insensitive mutants reveals a crosstalk between low phosphorus-induced determinate root development and the activation of genes involved in the adaptation of Arabidopsis to phosphorus deficiency. Plant Physiol. 140:879-889.

Saponari, M., Boscia, D., Altamura, G., Loconsole, G., Zicca, S., D’Attoma, G., Morelli, M., Palmisano, F., Saponari, A., Tavano, D., Savino, V. N., Dongiovanni, C., and Martelli, G. P. 2017. Isolation and pathogenicity of Xylella fastidiosa associated to the olive quick decline syndrome in southern Italy. Sci. Rep. 7:17723.

Saponari, M., Boscia, D., Nigro, F., and Martelli, G. P. 2013. Identification of DNA sequences related to Xylella fastidiosa in oleander, almond and olive trees exhibiting leaf scorch symptoms in Apulia (Southern Italy). Disease Note. J. Plant Pathol. 94:688.

Saporta, R., San Pedro, T., and Gisbert, C. 2016. Attempts at grapevine (Vitis vinifera L.) breeding through genetic transformation: The main limiting factors. Vitis J. Grapevine Res. 55:173-186.

Schenke, D., Böttcher, C., and Scheel, D. 2011. Crosstalk between abiotic ultraviolet-B stress and biotic (flg22) stress signalling in Arabidopsis prevents flavonol accumulation in favor of pathogen defence compound. Plant Cell Environ. 34:1849-1864.

Schlaich, N. L. 2011. Arabidopsis thaliana-The model plant to study host-pathogen interactions. Curr. Drug Targets 12:955-966.
Serrano, M., Kanehara, K., and Torres, M. 2012. Repression of sucrose/ ultraviolet B light-induced flavonoid accumulation in microbe-associated molecular pattern-triggered immunity in Arabidopsis. Plant Physiol. 158: 408-422.

Silva-Stenico, M. E., Pacheco, F. T., Pereira-Filho, E. R., Rodrigues, J. L., Souza, A. N., Etchegaray, A., Gomes, J. E., and Tsai, S. M. 2009. Nutritional deficiency in citrus with symptoms of citrus variegated chlorosis disease. Braz. J. Biol. 69:859-864.

Simpson, A. J., Reinach, F. C., Arruda, P., Abreu, F. A., Acencio, M., Alvarenga, R., Alves, L. M., Araya, J. E., Baia, G. S., Baptista, C. S., Barros, M. H., Bonaccorsi, E. D., Bordin, S., Bové, J. M., Briones, M. R., Bueno, M. R., Camargo, A. A., Camargo, L. E., Carraro, D. M., Carrer, H., Colauto, N. B., Colombo, C., Costa, F. F., Costa, M. C., Costa-Neto, C. M., Coutinho, L. L., Cristofani, M., Dias-Neto, E., Docena, c., El-Dorry, H., Facincani, A. P., Ferreira, A. J., Ferreira, V. C., Ferro, J. A., Fraga, J. S., França, S. C., Franco, M. C., Frohme, M., Furlan, L. R., Garnier, M., Goldman, G. H., Goldman, M. H., Gomes, S. L., Gruber, A., Ho, P. L., Hoheisel, J. D., Junqueira, M. L., Kemper, E. L., Kitajima, J. P., Krieger, J. E., Kuramae, E. E., Laigret, F., Lambais, M. R., Leite, L. C., Lemos, E. G., Lemos, M. V., Lopes, S. A., Lopes, C. R., Machado, J. A., Machado, M. A., Madeira, A. M., Madeira, H. M., Marino, C. L., Marques, M. V., Martins, E. A., Martins, E. M., Matsukuma, A. Y., Menck, C. F., Miracca, E. C., Miyaki, C. Y., Monteriro-Vitorello, C. B., Moon, D. H., Nagai, M. A., Nascimento, A. L., Netto, L. E., Nhani, A., Jr., Nobrega, F. G., Nunes, L. R., Oliveira, M. A., de Oliveira, M. C., de Oliveira, R. C., Palmieri, D. A., Paris, A., Peixoto, B. R., Pereira, G. A., Pereira, H. A., Jr., Pesquero, J. B., Quaggio, R. B., Roberto, P. G., Rodrigues, V., de M Rosa, A. J., de Rosa, V. E., Jr., de Sá, R. G., Santelli, R. V., Sawasaki, H. E., da Silva, A. C., da Silva, A. M., da Silva, F. R., da Silva, W. A., Jr., da Silveira, J. F., Silvestri, M. L., Siqueira, W. J., de Souza, A. A., de Souza, A. P., Terenzi, M. F., Triffi, D., Tsai, S. M., Tsuhako, M, H., Vallada, H., Van Sluys, M. A., Verjovski-Almeida, S., Vettore, A. L., Zago, M. A., Zatz, M., Meidanis, J., and Setubal, J. C. 2000. The genome sequence of the plant pathogen Xylella fastidiosa. Nature 406:151-157.

Tumber, K., Alston, J., and Fuller, K. 2014. Pierce's disease costs California $\$ 104$ million per year. Calif. Agric. 68:20-29.

Van Sluys, M. A., Monteiro-Vitorello, C. B., Camargo, L. E., Menck, C. F., Da Silva, A. C., Ferro, J. A., Oliveira, M. C., Setubal J. C., Kitajima, J. P., and Simpson, A. J. 2012. Comparative genomic analysis of plant-associated bacteria. Annu. Rev. Phytopathol. 40:169-89.

Wallis, C. M., and Chen, J. 2012. Grapevine phenolic compounds in xylem sap and tissues are significantly altered during colonization by Xylella fastidiosa. Phytopathology 102:816-826.

Wells, J. M., Raju, B. C., Nyland, G., and Lowe, S. K. 1981. Medium for isolation and growth of bacteria associated with plum leaf scald and phony peach diseases. Appl. Environ. Microbiol. 42:357-363.

Windram, O., Madhou, P., McHattie, S., Hill, C., Hickman, R., Cooke, E., Jenkins, D. J., Penfold, C. A., Baxter, L., Breeze, E., Kiddle, S. J., Rhodes, J., Atwell, S., Kliebenstein, D. J., Kim, Y. S., Stegle, O., Borgwardt, K., Zhang, C., Tabrett, A., Legaie, R., Moore, J., Finkenstadt, B., Wild, D. L., Mead, A., Rand, D., Beynon, J., Ott, S., Buchanan-Wollaston, V., and Denby, K. J. 2012. Arabidopsis defense against Botrytis cinerea: Chronology and regulation deciphered by high-resolution temporal transcriptomic analysis. Plant Cell 24:3530-3557.

Witzel, K., Hanschen, F. S., Klopsch, R., Ruppel, S., Schreiner, M., and Grosch, R. 2015. Verticillium longisporum infection induces organ-specific glucosinolate degradation in Arabidopsis thaliana. Front. Plant Sci. 6:508.

Yang, L., Lin, H., Takahashi, Y., Chen, F., Walker, M. A., and Civerolo, E. L. 2011. Proteomic analysis of grapevine stem in response to Xylella fastidiosa inoculation. Physiol. Mol. Plant Pathol. 75:90-99.

Zhang, W., Corwin, J. A., Copeland, D., Feusier, J., Eshbaugh, R., Chen, F., Atwell, S., and Kliebenstein D. J. 2017. Plastic transcriptomes stabilize immunity to pathogen diversity: The jasmonic acid and salicylic acid networks within the Arabidopsis/Botrytis pathosystem. The Plant Cell 29: 2727-2752. 